Bài báo khoa học

\title{
Đánh giá hiệu quả của các công trình kè giảm sóng tại bờ biển Tây tỉnh Cà Mau
}

\author{
Nguyễn Ngọc Thuận ${ }^{1}$, Trần Văn Tỷ ${ }^{2 *}$, Trần Văn Hừng ${ }^{2}$, Huỳnh Thị Cẩm Hồng ${ }^{2}$, Hà \\ Ngọc Nhạn², Trần Hải Lâm², Đinh Văn $D^{2} y^{2}$, Trần Khánh Hải ${ }^{3}$, Trịnh Văn Tuấn ${ }^{3}$, \\ Trần Minh Quảng ${ }^{3}$
}

${ }^{1}$ Công Ty CP Lắp Đặt Điện Nước IEE-24/7; congtyiee24.7@gmail.com

${ }^{2}$ Khoa Công nghệ, Trường Đại học Cần Thơ; tvty@ctu.edu.vn; tranvanhung@ctu.edu.vn; htchong@ctu.edu.vn; nhanb1705842@student.ctu.edu.vn; lamb1606132@student.ctu.edu.vn; dvduy@ctu.edu.vn

${ }^{3}$ Sở Nông nghiệp Phát triển Nông thôn tỉnh Cà Mau; trankhanhhaisd@gmail.com; tuan0917177478@gmail.com; tranminhquangkbtb@gmail.com

*Tác giả liên hệ: tvty@ctu.edu.vn; Tel.: +84-939501909.

Ban Biên tập nhận bài: 12/09/2021; Ngày phản biện xong: 09/10/2021; Ngày đăng bài: $25 / 12 / 2021$

Tóm tắt: Mục tiêu của nghiên cứu này là đánh giá diễn biến đường bờ biển và hiệu quả giảm sóng của các công trình kè giảm sóng tại bờ biển Tây tỉnh Cà Mau. Ảnh Landsat và ảnh tải về bằng công cụ Google earth (ảnh Google earth) được sử dụng để quan sát diễn biến đường bờ biển. Số liệu sóng phía trước và sau kè được đo đạc và phân tích để đánh giá hiệu quả giảm sóng của các loại kè. Kết quả phân tích ảnh cho thấy diện tích rừng phòng hộ bị suy giảm nghiêm trọng (khoảng 160 ha) trong 20 năm qua với tốc độ suy giảm là 7,76 và 8,18 ha/năm lần lượt đối với ảnh Landsat và Google earth. Kết quả đo sóng cho thấy hiệu quả giảm chiều cao sóng tương ứng với $\mathrm{h}_{\max }, 1 / 10 \mathrm{~h}_{\max }, 1 / 3 \mathrm{~h}_{\max }$ và $\mathrm{h}_{\mathrm{tb}}$ của kè ly tâm lần lượt là $86 \%, 83 \%, 82 \%$ và $81 \%$. Tương tự với kè Busadco lần lượt là $79 \%, 89 \%, 90 \%$ và $90 \%$; kè bán nguyệt lần lượt là $83 \%, 82 \%, 81 \%$, và $80 \%$. Hiệu quả giảm năng lượng sóng của cả ba loại kè đều đạt trên $95 \%$. Kết quả nghiên cứu dựa trên dữ liệu đo đạc trong một khoảng thời gian ngắn nên chưa thể kết luận về hiệu quả cho toàn bộ các dạng kè này.

Từ khóa: Biển Tây tỉnh Cà Mau; Ảnh viễn thám; Hiệu quả giảm sóng; Kè ly tâm; Kè bán nguyệt; Kè Busadco.

\section{Mở đầu}

Cà Mau là một tỉnh cực Nam của Việt Nam và Đồng bằng sông Cửu Long (ĐBSCL). Đây là một vùng đất trũng với phần lớn diện tích có cao độ dưới $+1,5 \mathrm{~m}$ [1]. Ba mặt của tỉnh Cà Mau được bao phủ bởi Biển Đông và Vịnh Thái Lan. Cà Mau có 240,4 km đường bờ biển [2] và 187.553 ha rừng ngập mặn [3]. Trong đó, bờ biển của Cà Mau cấu tạo chủ yếu bởi đất sét và bùn với hình thái đường bờ chịu tác động chủ yếu của sóng (wave-dominated coast) [2]. Trong những thập kỷ gần đây, xói lở bờ biển và mất dần diện tích rừng phòng hộ đang là một vấn đề nghiêm trọng xảy ra ở Cà Mau. Cụ thể, chiều dài đoạn xói lở bờ biển Tây đã kéo dài $50 \mathrm{~km}$ từ Kiên Giang đến Cà Mau [4]. Trước tình trạng sạt lở bờ biển đang diê̂̉n ra ngày càng nghiêm trọng, một tuyến kè biển dọc theo bờ biển Tây đã được xây dựng nhằm mục đích giảm tác động của sóng và phục hồi lại bãi biển (Hình 1). Có ba loại kết cấu chính trong tuyến kè biển này là kè cọc ly tâm, kè Busadco và kè bán nguyệt với chiều dài tổng 
cộng từ Hòn Đá Bạc đến cửa Kênh Mới khoảng $5 \mathrm{~km}$. Trong đó, kè bán nguyệt được hoàn thành vào năm 2017 và cả tuyến kè hiện hữu được hoàn thành vào năm 2019.

Trong những năm gần đây, đã có một số công trình nghiên cứu về tuyến kè biển Tây như đánh giá ổn định của tuyến kè bán nguyệt dài $180 \mathrm{~m}$ bằng phân tích ổn định lật, trượt và quan trắc lún kết hợp với mô hình phần tử hữu hạn [5]; đánh giá hiệu quả giảm sóng và tạo bãi của đê trụ rỗng [6]; đánh giá hiệu quả giảm sóng của kè Busadco tại biển Đông và biển Tây tỉnh Cà Mau bằng phương pháp quan trắc số liệu sóng trước và sau công trình kết hợp với phương pháp chập bản đồ từ nguồn ảnh Google earth [7]; đánh giá hiệu quả giảm sóng và tạo bãi của kè cọc ly tâm bằng phương pháp khảo sát số liệu sóng và hàm lượng bùn cát lơ lửng [8-9]. Hiện tại, chưa có một nghiên cứu tổng thể đánh giá hiệu quả giảm sóng của cả ba loại kè biển trong tuyến kè biển Tây. Vì vậy, mục tiêu của nghiên cứu này là đánh giá diễn biến đường bờ biển sử dụng ảnh Landsat và Google Earth để quan sát diễn biến đường bờ biển Tây trong phạm vi $5 \mathrm{~km}$ và hiệu quả giảm sóng của các công trình giảm sóng tại bờ biển Tây tỉnh Cà Mau theo số liệu sóng được đo đạc trực tiếp tại hai vị trí (trong và ngoài kè) của từng loại kè (kè ly tâm, kè Busadco và kè bán nguyệt).

Để ứng phó với những thách thức trong việc phòng chống sạt lở bờ biển Tây, tỉnh Cà Mau trong thời gian qua đã áp dụng thử nghiệm nhiều giải pháp công trình để bảo vệ bờ biển, bảo vệ đê biển như giải pháp kè bằng cọc ly tâm, kè Busadco và kè bán nguyệt. Qua quan sát thực tế cho thấy các giải pháp này bước đầu đã cho thấy một số ưu điểm so với các loại khác. Tuy nhiên, chưa có nghiên cứu quan trắc để đánh giá mức độ giảm sóng qua các dạng kè cũng như hiệu quả tạo bồi phía trong kè cho các tuyến kè giảm sóng tại ĐBSCL nói chung và ba loại kè biển Tây tỉnh Cà Mau nói riêng. Do đó, nghiên cứu này tập trung phân tích hiệu quả giảm sóng và tạo bãi của tuyến kè dài tổng cộng khoảng $5 \mathrm{~km}$ từ Kênh Đá Bạc đến cửa Kênh Mới với ba loại kết cấu kè theo thứ tự từ Bắc xuống Nam là kè ly tâm, kè Busadco và kè bán nguyệt (Hình 1).
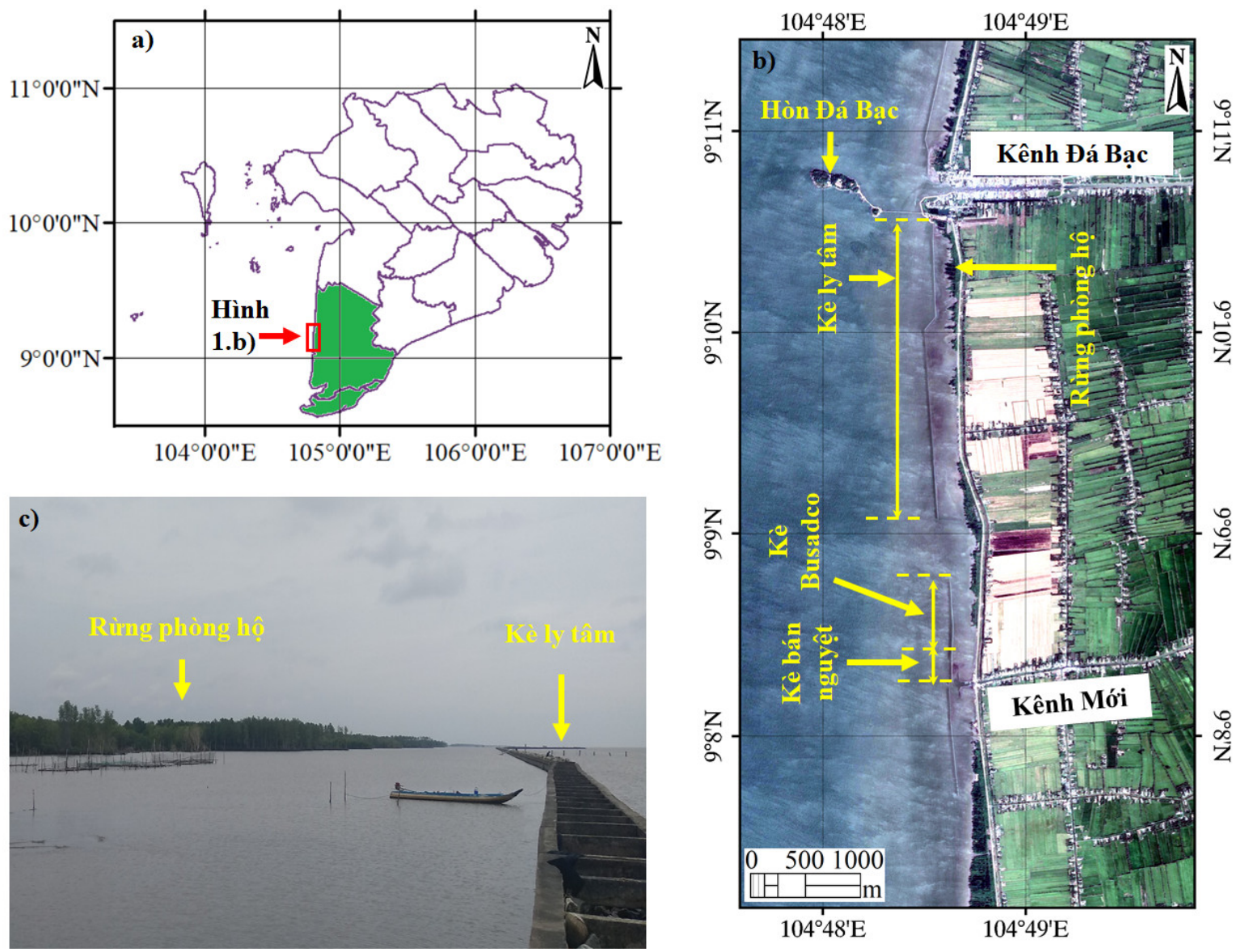

Hình 1. Khu vực nghiên cứu. 


\section{Phương pháp nghiên cứu}

Phương pháp nghiên cứu được mô tả như trong sơ đồ trên Hình 2.

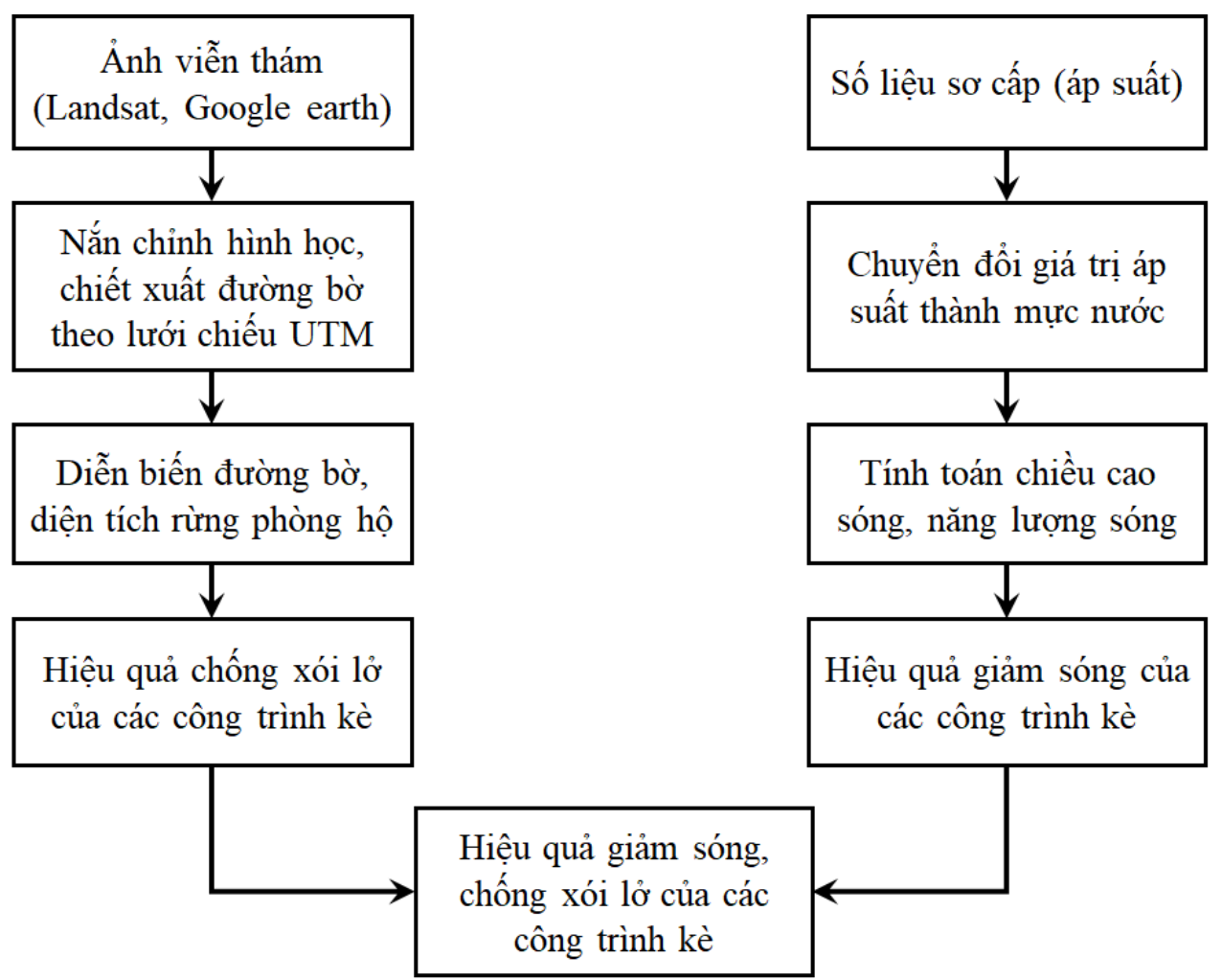

Hình 2. Sơ đồ cấu trúc các bước nghiên cứu.

\subsection{Phân tích ảnh viễn thám}

Ảnh vệ tinh Landsat và ảnh Google earth được sử dụng kết hợp để đánh giá diễn biến đường bờ và diện tích rừng phòng hộ khu vực nghiên cứu. Trong đó, ảnh Google earth có độ phân giải cao được sử dụng làm chuẩn để đánh giá độ tin cậy của kết quả phân tích từ ảnh Landsat có độ phân giải thấp hơn (trung bình $30 \mathrm{~m} /$ pixel).

- Ảnh Landsat: Đối với ảnh Landsat, các ảnh này đã được nắn chỉnh về cùng hệ tọa độ trong lưới chiếu UTM nên trong quá trình phân tích không cần thực hiện nắn chỉnh hình học mà chỉ thực hiện việc giải đoán đường bờ. Ảnh vệ tinh Landsat 5 và 8 từ năm 2000 đến năm 2020 được sử dụng để đánh giá biến động đường bờ và diện tích rừng phòng hộ dọc theo tuyến kè. Phương pháp tách ranh giới nước-đất liền được thực hiện theo các nghiên cứu trước đây [10-11]. Cụ thể, chỉ số nước khác biệt chuẩn hóa NDWI được sử dụng để giải đoán đường bờ biển cho các ảnh Landsat với độ chính xác có thể đạt đến 90,48\% [12] theo công thức [13]:

$$
\mathrm{NDWI}=\frac{\text { GREEN }- \text { NIR }}{\text { GREEN }+ \text { NIR }}
$$

Trong đó GREEN là kênh ánh sáng lục và NIR là kênh cận hồng ngoại.

Đối với ảnh Landsat 5, GREEN là kênh 2 và NIR là kênh 4 [14] nên ta có:

$$
\text { NDWI }=\frac{\text { Kênh } 2-\text { Kênh } 4}{\text { Kênh } 2+\text { Kênh } 4}
$$

Đối với ảnh Landsat 8 , GREEN là kênh 3 và NIR là kênh 5 [15] nên ta có:

$$
\text { NDWI }=\frac{\text { Kênh } 3-\text { Kênh } 5}{\text { Kênh } 3+\text { Kênh } 5}
$$


Phần mềm ArcGIS được sử dụng để phân loại ảnh chỉ số nước thành vùng đất và nước sử dụng công cụ Reclassify. Dữ liệu raster vùng đất và nước được chuyển thành các Polygon và lưu dưới dạng tập tin .dwg. Số liệu về các ảnh Landsat được trình bày trong Bảng 1 .

Bảng 1. Số liệu ảnh Landsat.

\begin{tabular}{cccccc}
\hline Thò̀ gian & Vệ tinh & Bộ cảm & $\begin{array}{c}\text { Độ phân giải } \\
(\mathbf{m})\end{array}$ & $\begin{array}{c}\text { Tỷ lệ mây } \\
\mathbf{( \% )}\end{array}$ & Hệ tọa độ \\
\hline $10 / 03 / 2000$ & Landsat 5 & TM & 30 & 13,00 & UTM \\
$08 / 01 / 2001$ & Landsat 5 & TM & 30 & 5,00 & UTM \\
$16 / 12 / 2003$ & Landsat 5 & TM & 30 & 34,00 & UTM \\
$02 / 02 / 2004$ & Landsat 5 & TM & 30 & 2,00 & UTM \\
$19 / 01 / 2005$ & Landsat 5 & TM & 30 & 1,00 & UTM \\
$07 / 02 / 2006$ & Landsat 5 & TM & 30 & 4,00 & UTM \\
$02 / 06 / 2007$ & Landsat 5 & TM & 30 & 5,00 & UTM \\
$13 / 02 / 2008$ & Landsat 5 & TM & 30 & 9,00 & UTM \\
$14 / 01 / 2009$ & Landsat 5 & TM & 30 & 0,00 & UTM \\
$28 / 07 / 2010$ & Landsat 5 & TM & 30 & 28,00 & UTM \\
$29 / 06 / 2011$ & Landsat 5 & TM & 30 & 20,00 & UTM \\
$27 / 12 / 2013$ & Landsat 8 & OLI_TIRS & 30 & 17,32 & UTM \\
$28 / 01 / 2014$ & Landsat 8 & OLI_TIRS & 30 & 10,72 & UTM \\
$21 / 04 / 2015$ & Landsat 8 & OLI_TIRS & 30 & 0,02 & UTM \\
$19 / 02 / 2016$ & Landsat 8 & OLI_TIRS & 30 & 0,25 & UTM \\
$20 / 01 / 2017$ & Landsat 8 & OLI_TIRS & 30 & 12,67 & UTM \\
$12 / 03 / 2018$ & Landsat 8 & OLI_TIRS & 30 & 7,42 & UTM \\
$27 / 02 / 2019$ & Landsat 8 & OLI_TIRS & 30 & 5,29 & UTM \\
$13 / 01 / 2020$ & Landsat 8 & OLI_TIRS & 30 & 6,38 & UTM \\
\hline
\end{tabular}

- Ảnh Google earth: Các ảnh chất lượng cao được tải về từ phần mềm Google earth cũng được sử dụng để so sánh với kết quả giải đoán của ảnh Landsat nhằm đánh giá độ tin cậy của việc sử dụng ảnh Landsat. Các ảnh Google earth được tải về có độ phân giải $1,0 \mathrm{~m}$. Số liệu về ảnh Google earth được trình bày trong Bảng 2 .

Bảng 2. Số liệu ảnh Google earth.

\begin{tabular}{ccc}
\hline Thời gian & Độ phân giải $(\mathbf{m})$ & Hệ tọa độ \\
\hline $03 / 02 / 2001$ & 1,0 & UTM \\
$03 / 11 / 2013$ & 1,0 & UTM \\
$13 / 01 / 2015$ & 1,0 & UTM \\
$31 / 10 / 2018$ & 1,0 & UTM \\
$23 / 01 / 2020$ & 1,0 & UTM \\
\hline
\end{tabular}

Để đảm bảo độ phân giải của ảnh Google earth, khu vực nghiên cứu được chia thành 12 khung ảnh nhỏ. Các khung ảnh sau khi tải về sẽ được gán tọa độ bằng phần mềm ArcGIS và ghép lại với nhau để tạo thành một khung ảnh lớn bao phủ toàn bộ tuyến kè bằng chức năng Mosaic trong phần mềm ENVI. Vì ảnh tải về từ phần mềm Google earth không cùng khung hình học nên các ảnh này được nắn chỉnh hình học bằng chức năng Registration trong bộ công cụ Map của ENVI trước khi tiến hành phân tích giải đoán đường bờ. Sai số trung bình bình phương (RMSE) được sử dụng để đánh giá độ chính xác của việc nắn chỉnh ảnh theo công thức:

$$
\mathrm{RMSE}=\sqrt{\sum_{\mathrm{i}=1}^{\mathrm{n}} \frac{\left(\widehat{\mathrm{y}}_{\mathrm{i}}-\mathrm{y}_{\mathrm{i}}\right)^{2}}{\mathrm{n}}}
$$

Trong đó $\mathrm{y}_{\mathrm{i}}$ là tọa độ điểm khống chế thứ $\mathrm{I} ; \hat{\mathrm{y}}_{\mathrm{i}}$ là giá trị ước đoán bằng mô hình hồi quy tuyến tính tại điểm khống chế thứ $i$, và y là giá trị trung bình cộng của tất cả các giá trị $\mathrm{y}_{\mathrm{i}}$. 
Ảnh tải về từ Google earth là ảnh toàn sắc nên không thể sử dụng các phương pháp phân loại kiểm định hoặc không kiểm định để giải đoán đường bờ một cách tự động. Tuy nhiên, ảnh Google earth có ưu điểm là độ phân giải cao nên có thể dễ dàng quan sát được các chi tiết trên ảnh (công trình, đường giao thông, vùng nước...) bằng mắt thường. Vì vậy, nghiên cứu này sử dụng phương pháp thủ công để chiết xuất đường bờ từ các ảnh Google earth [16]. Độ chính xác của phương pháp chiết xuất đường bờ một cách thủ công được thảo luận lần đầu tiên vào năm 1956 [17]. Đây là phương pháp phụ thuộc rất nhiều vào kinh nghiệm của kỹ thuật viên và kiến thức của kỹ thuật viên về khu vực nghiên cứu [18]. Theo [19], sai số giải đoán đường bờ bằng phương pháp thủ công sử dụng ảnh toàn sắc IKONOS có độ phân giải xấp xỉ 1,0 $\mathrm{m}$ dao động trong khoảng từ 2,0-4,0 $\mathrm{m}$.

- Tính toán sự thay đổi diện tích rừng phòng hộ

Cùng với việc đánh giá diễn biến đường bờ (đai rừng phòng hộ), diện tích rừng phòng hộ qua các năm cũng được tính toán để đánh giá biến động diện tích rừng phòng hộ và bước đầu đánh giá hiệu quả ngăn xói lở bờ biển của các công trình kè. Diện tích rừng phòng hộ được tính toán dựa vào bốn đường biên bao gồm đường bờ, tuyến đê phía sau rừng phòng hộ và hai đường thẳng song song nối điểm đầu và điểm cuối tuyến đê với đường bờ. Tuyến để được giới hạn bởi hai điểm $\mathrm{A}\left(104^{\circ} 48,639^{\prime} \mathrm{E}\right.$; $\left.9^{\circ} 10,549^{\prime} \mathrm{N}\right)$ và $\mathrm{B}\left(104^{\circ} 48,793^{\prime} \mathrm{E}\right.$; $9^{\circ} 7,855^{\prime}$ N) như trong Hình 3.

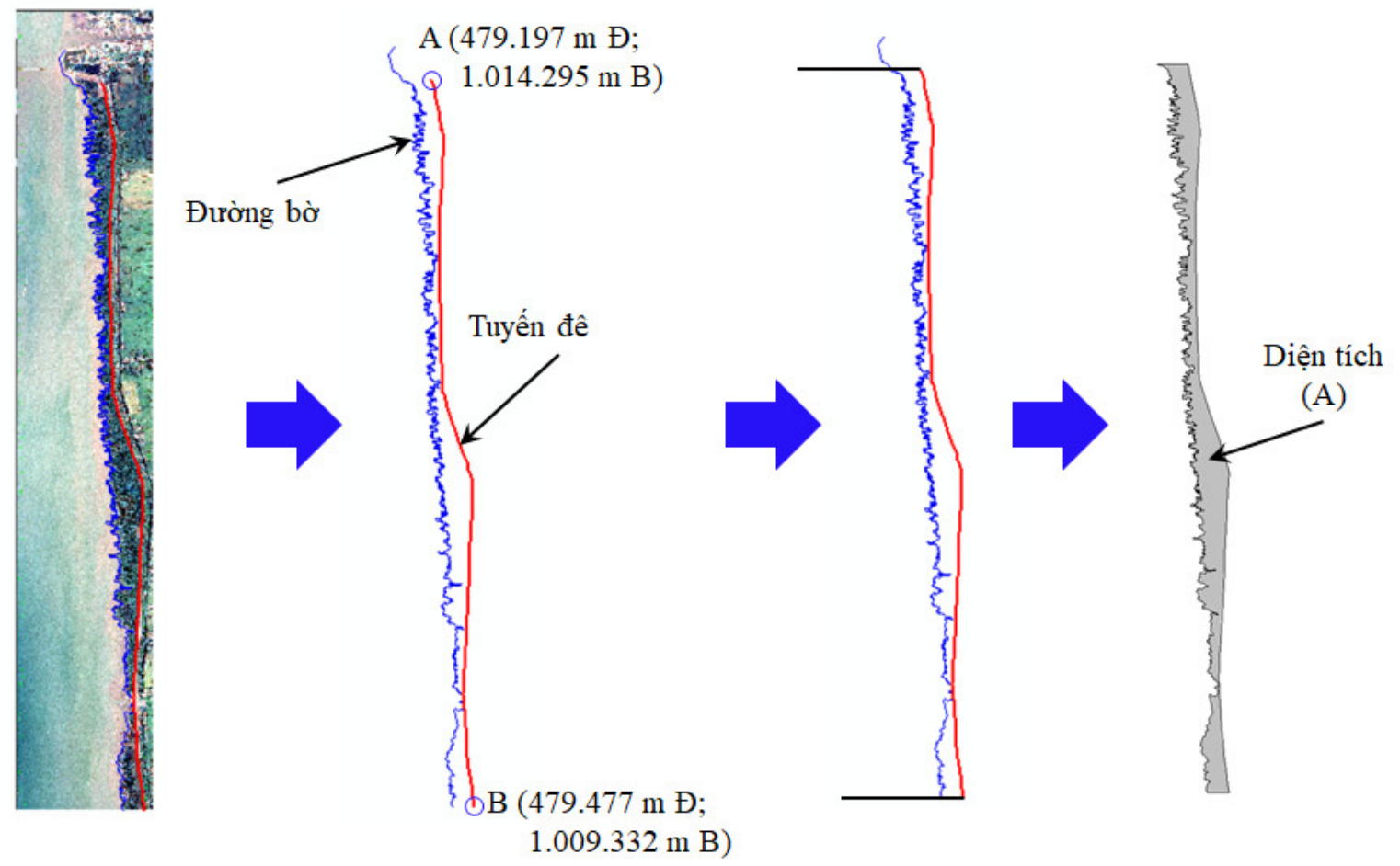

Hình 3. Phương pháp tính diện tích rừng phòng hộ.

\subsection{Số liệu sóng}

- Công tác chuẩn bị: Hai thiết bị đo mực nước Levelogger® 5 Junior của hãng Solinst (Canada) và INFINITY-WH AWH-USB của hãng JFE Advantech (Nhật Bản) được sử dụng để đo chiều cao sóng. Các thiết bị được cố định vào cây tràm và được đặt tại hai vị trí cách đều tâm tuyến kè $10 \mathrm{~m}$ về phía biển và phía bờ. Tại phía biển, thiểt bị đo Levelogger® 5 Junior được sử dụng và đặt ở cao trình cách mặt đất tự nhiên khoảng $1,0 \mathrm{~m}$. Tại phía bờ, thiết bị INFINITY-WH AWH-USB được sử dụng và đặt ở cao trình xấp xỉ -1,0 m (cách mặt đất tự nhiên $0,2 \mathrm{~m}$ ). Số liệu mực nước được ghi nhận với chu kỳ $01 \mathrm{~s}$ trong ngày 15/10/2020. Công tác lắp đặt thiết bị đo được thực hiện bởi hai thợ lặn chuyên nghiệp người bản địa. Sơ họa mặt bằng bố trí thiết bị đo như Hình 4 . 
a)
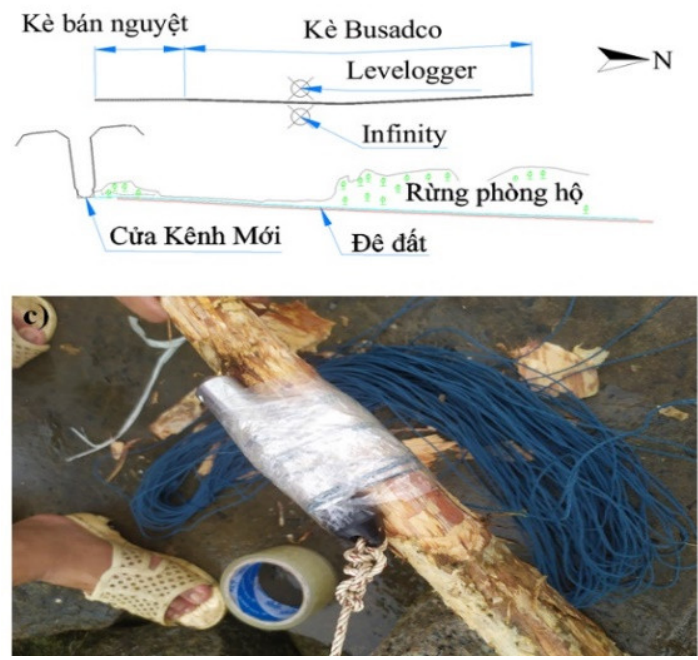

b)
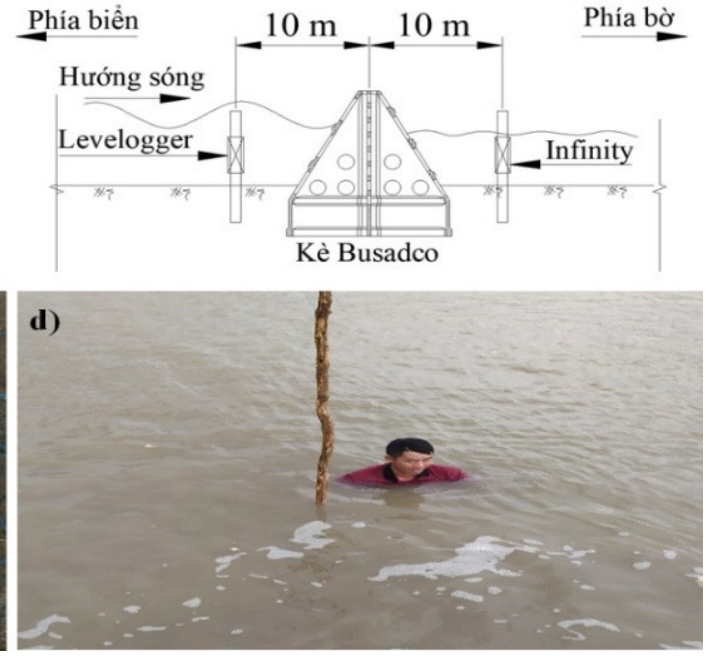

Hình 4. Bố trí thiết bị đo mực nước: (a) Sơ họa mặt bằng bố trí thiết bị đo; (b) Mặt cắt; (c) Cố định thiết bị Levelogger vào cây tràm; (d) Lắp đặt thiết bị đo vào vị trí.

- Xử lý số liệu: Số liệu đo đạc mực nước tại các vị trí trước và sau công trình giảm sóng được xử lý để xác định chiều cao sóng theo [20]. Để thuận tiện cho việc tính toán, quy trình xử lý dữ liệu đã được lập trình thành các hàm trong trong ngôn ngữ lập trình Matlab và $R$ và có thể tải về miễn phí từ các trang web của các tác giả [21].

\section{3. Đánh giá hiệu quả giảm sóng của các công trình kè}

Hiệu quả giảm sóng được đánh giá theo TCVN 12261:2018 [22]. Chiều cao của sóng biển ở khu vực phía sau công trình giảm sóng, ký hiệu là $\mathrm{H}_{\mathrm{t}}$, được xác định theo công thức:

$$
\mathrm{H}_{\mathrm{t}}=\mathrm{K}_{\mathrm{tr}} \times \mathrm{H}_{\mathrm{sp}}
$$

Trong đó $\mathrm{H}_{\mathrm{sp}}$ là chiều cao của sóng biển phía trước công trình $(\mathrm{m})$; $\mathrm{K}_{\mathrm{tr}}$ là hệ số truyền sóng. $K_{\text {tr }}$ phụ thuộc vào khoảng cách từ đỉnh công trình tới mực nước biển thiết kế $\left(\mathrm{h}_{\mathrm{c}}\right)$ và chiều cao sóng biển ở phía trước công trình $\left(\mathrm{H}_{\mathrm{sp}}\right)$.

Hiệu quả giảm sóng được tính theo công thức:

$$
\varepsilon=\left(1-\mathrm{K}_{\mathrm{tr}}\right) \times 100 \%
$$

Các trường hợp xem xét tính toán mức độ giảm sóng dựa trên các kết quả đo đạc thực tế cho ba trường hợp: (a) Trung bình $1 / 10$ sóng lớn nhất $\left(1 / 10 \mathrm{~h}_{\max }\right)$; (b) Trung bình $1 / 3$ sóng lớn nhất $\left(1 / 3 h_{\max }\right)$; và $(\mathrm{c})$ Sóng trung bình $\left(\mathrm{h}_{\mathrm{tb}}\right)$. Năng lượng sóng trước và sau công trình cũng được tính toán để đánh giá hiệu quả giảm năng lượng sóng. Năng lượng sóng toàn phần được xác định theo công thức:

$$
\mathrm{E}=\mathrm{E}_{\mathrm{p}}+\mathrm{E}_{\mathrm{d}}=\frac{1}{8} \times \rho \times \mathrm{g} \times \mathrm{H}^{2}
$$

Trong đó $\mathrm{E}$ là năng lượng toàn phần của sóng, $\mathrm{E}_{\mathrm{p}}$ là thế năng của sóng; $\mathrm{E}_{\mathrm{d}}$ là động năng của sóng; $\rho$ là khối lượng riêng nước biển $\left(\mathrm{kg} / \mathrm{m}^{3}\right)$; $\mathrm{g}$ là gia tốc trọng trường $\left(\mathrm{m} / \mathrm{s}^{2}\right)$ và $\mathrm{H}$ là chiều cao sóng lấy trung bình của $1 / 10 \mathrm{~h}_{\max }(\mathrm{m})$.

Hiệu quả giảm năng lượng sóng được tính theo công thức:

$$
\mathrm{K}_{\mathrm{gs}}=\left(1-\frac{\mathrm{E}_{\mathrm{s}}}{\mathrm{E}_{\mathrm{t}}}\right) \times 100
$$

Trong đó $\mathrm{K}_{\mathrm{gs}}$ là phần trăm giảm sóng, $\mathrm{E}_{\mathrm{s}}$ là năng lượng sóng sau kè; $\mathrm{E}_{\mathrm{t}}$ là năng lượng sóng trước kè. 


\section{Kết quả và thảo luận}

\subsection{Kết quả nắn chỉnh hình học ảnh Google earth}

Kết quả nắn chỉnh hình học ảnh Google earth được thể hiện trong Bảng 3. Số liệu các điểm khống chế dùng để nắn chỉnh ảnh cũng được trình bày. Tất cả các ảnh đều có số lượng điểm khống chế mặt đất bằng 10 trừ ảnh chụp năm 2001 vì tại năm 2001 có rất ít công trình được xây dựng nên số lượng điểm khống chế bị hạn chế so với các ảnh chụp trong những năm gần đây. Có thể nhận thấy sai số nắn chỉnh hình học các ảnh đều thấp hơn $1,0 \mathrm{~m}$ ngoại trừ ảnh chụp ngày $03 / 02 / 2001$ có sai số bằng $1,1 \mathrm{~m}$ vì chất lượng các điểm khống chế trong ảnh chụp ngày 03/02/2001 không được tốt như các ảnh chụp gần đây. Sai số của ảnh chụp ngày 23/01/2020 bằng 0 vì ảnh này được chọn làm ảnh gốc để nắn chỉnh các ảnh khác về khung hình học của ảnh này.

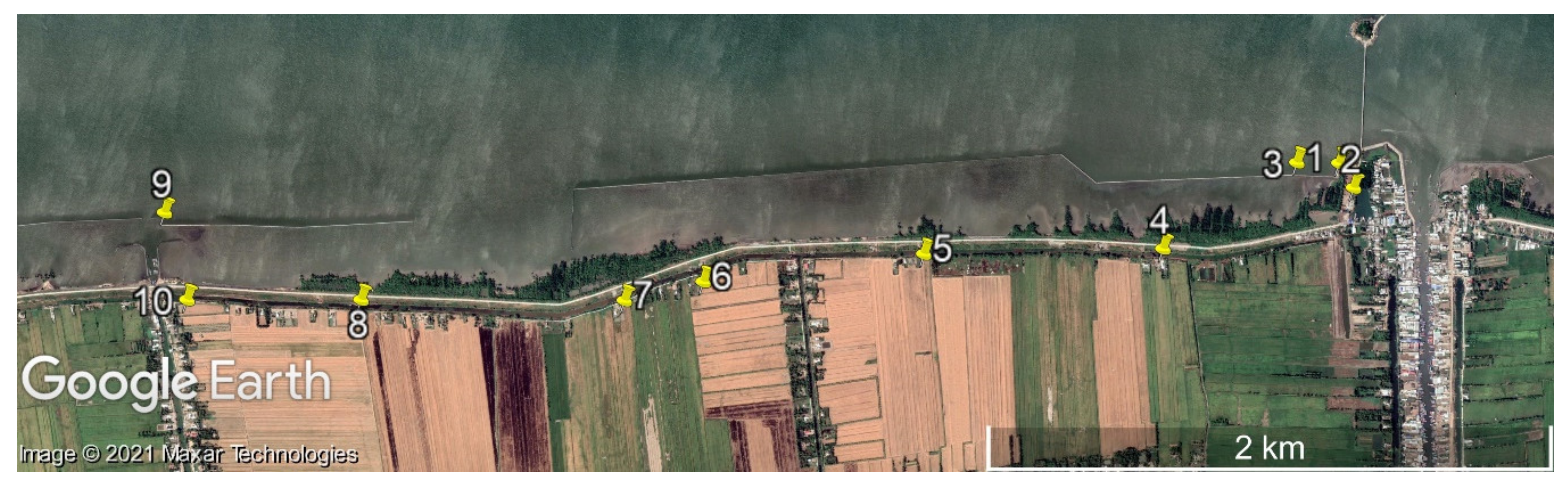

Hình 5. Sơ đồ các điểm khống chế.

Bảng 3. Sai số nắn chỉnh hình học ảnh.

\begin{tabular}{ccc}
\hline Thò̀i gian & Số điểm khống chế mặt đất & RMSE (m) \\
\hline $03 / 02 / 2001$ & 7 & 1,10 \\
$03 / 11 / 2013$ & 10 & 0,47 \\
$13 / 01 / 2015$ & 10 & 0,32 \\
$31 / 10 / 2018$ & 10 & 0,31 \\
$23 / 01 / 2020$ & 10 & 0,00 \\
\hline
\end{tabular}

\subsection{Biến động đường bò̀ và diện tích rùng phòng hộ}

Biến động đường bờ biển khu vực nghiên cứu được trình bày như trong Hình 6 . Có thể nhận thấy trong năm 2001, bề rộng rừng phòng hộ tại khu vực nghiên cứu vẫn còn rất lớn. Đến năm 2013, một phần lớn rừng phòng hộ tại khu vực này đã biến mất. Điều này thể hiện bằng biến động rất lớn của vị trí đường bờ. Cụ thể, so với năm 2001, đường bờ năm 2013 đã bị xói lở nghiêm trọng từ $200 \mathrm{~m}$ đến $300 \mathrm{~m}$. Trong giai đoạn từ 2013 đến 2015 , đường bờ tiếp tục bị xói lở tuy nhiên mức độ xói lở không nghiêm trọng. Giai đoạn 2015-2018, đường bờ lại tiếp tục xói lở nghiêm trọng với vị trí xói lở lớn nhất lên đến $100 \mathrm{~m}$. Từ năm 2018 đến năm 2020, vị trí đường bờ không có nhiều biến động. Tuyến kè bán nguyệt được hoàn thiện vào năm 2017 và toàn bộ tuyến kè biển Tây tại khu vực nghiên cứu được hoàn thiện vào năm 2019. Đây có thể là nguyên nhân làm giảm mức độ xói lở đường bờ giữa năm 2018 và 2020 .

Biến động diện tích rừng phòng hộ giai đoạn 2000-2020 được trình bày như trong Hình 7 với cả hai chuỗi dữ liệu giải đoán từ ảnh Landsat và ảnh Google earth. Ảnh tải về bằng công cụ Google earth có độ phân giải tốt hơn được sử dụng để làm chuẩn. Có thể nhận thấy diện tích rừng phòng hộ đã giảm khoảng 160 ha trong hai mươi năm qua với vận tốc giảm bằng 7,76 ha/năm đối với ảnh Landsat và 8,18 ha/năm đối với ảnh Google earth. Như vậy, sai số giữa việc sử dụng ảnh Landsat và ảnh Google earth trong tính toán vận tốc thay đồi diện tích rừng phòng hộ là $5 \%$. Điều này chứng tỏ độ tin cậy của việc sử dụng ảnh Landsat. 
Trong chuỗi số liệu ảnh Google earth, có thể nhận thấy giữa các năm 2018 và 2020, vận tốc suy giảm diện tích rừng phòng hộ có xu hướng giảm. Việc hoàn thiện xây dựng tuyến kè bán nguyệt trong năm 2017 và tuyến kè ly tâm trong năm 2019 có thể là nguyên nhân làm chậm quá trình xói lở rừng phòng hộ. Tuy nhiên, đây chỉ là kết quả quan sát dựa trên dữ liệu ảnh trong hai năm 2018 và 2020 . Cần tiếp tục thu thập ảnh và giải đoán cho các năm tiếp theo mới có cơ sở đánh giá chính xác hiệu quả chống xói lở bờ biển của các loại kè.

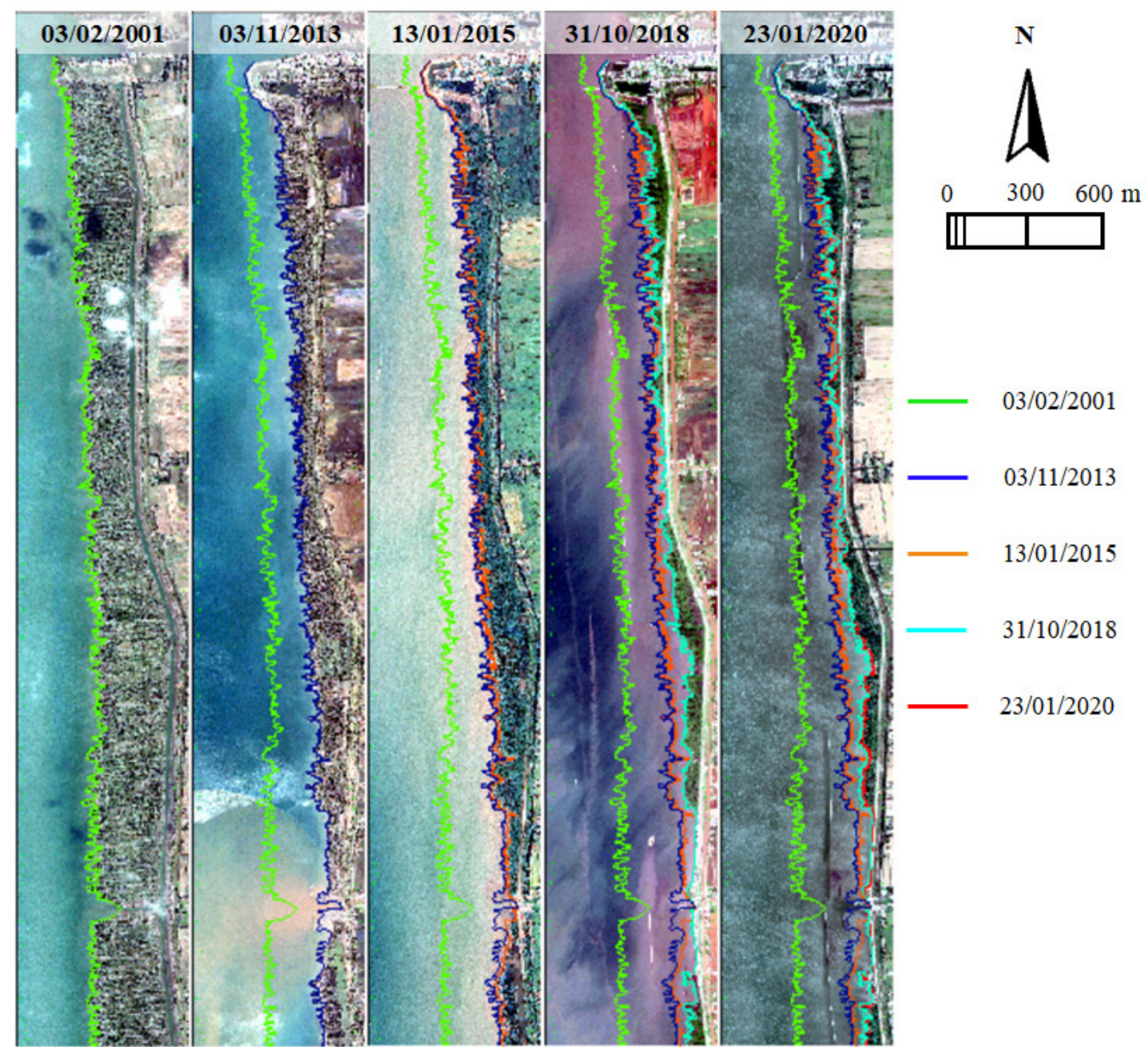

Hình 6. Biến động đường bờ khu vực nghiên cứu.

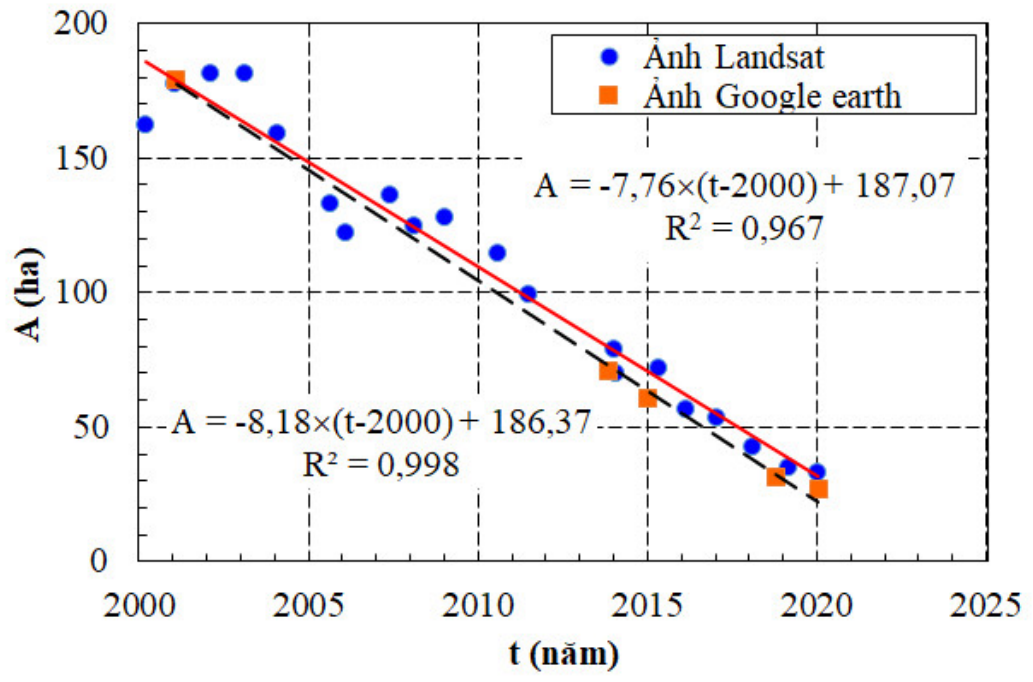

Hình 7. Biến động diện tích rừng phòng hộ. 


\subsection{Phân tích và đánh giá hiệu quả giảm sóng}

Chiều cao sóng và phần trăm tương ứng của sóng phía biển (phía trước) và phía bờ (phía sau) của các công trình kè giảm sóng được trình bày như trên Hình 8 . Có thể nhận thấy phía trước kè ly tâm, sóng có chiều cao từ $0,3 \mathrm{~m}$ đến $0,4 \mathrm{~m}$ chiếm tỷ lệ lớn nhất và phía sau kè ly tâm, sóng có chiều cao từ $0,06 \mathrm{~m}$ đến $0,07 \mathrm{~m}$ chiếm đa số. Đối với kè Busadco, sóng phía trước công trình có chiều cao từ $0,4 \mathrm{~m}$ đến $0,5 \mathrm{~m}$ chiếm đa số và sóng phía sau công trình có chiều cao từ $0,04 \mathrm{~m}$ đến $0,05 \mathrm{~m}$ chiếm đa số. Đối với kè bán nguyệt, sóng phía trước công trình có chiều cao từ $0,4 \mathrm{~m}$ đến $0,5 \mathrm{~m}$ chiếm đa số và sóng phía sau công trình có chiều cao từ $0,08 \mathrm{~m}$ đến $0,09 \mathrm{~m}$ chiếm đa số.

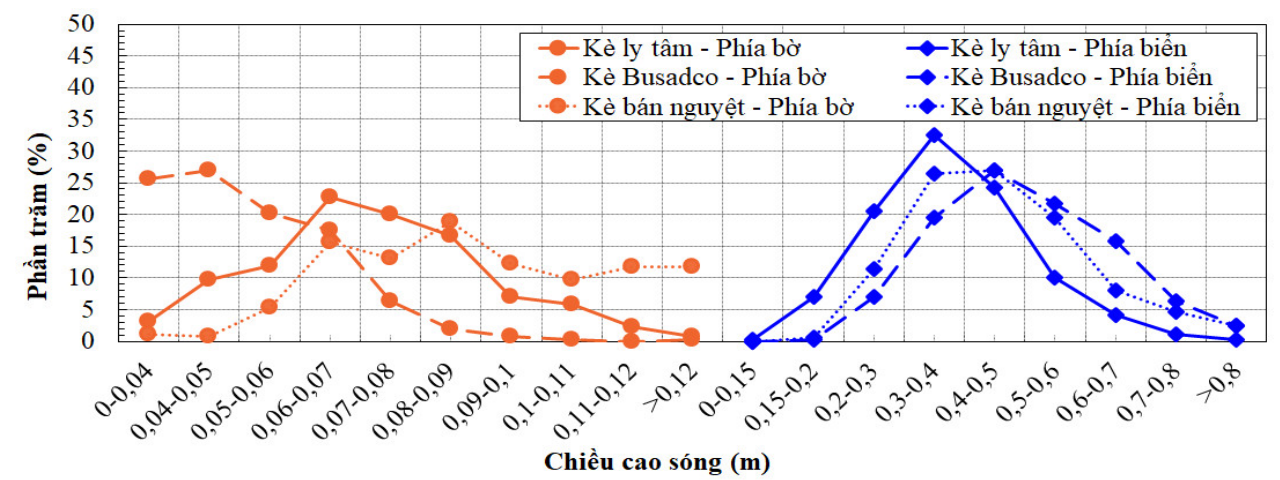

Hình 8. Biểu đồ quan hệ chiều cao và phần trăm sóng trước và sau kè ly tâm, kè Busadco và kè bán nguyệt.

Chiều cao sóng ứng với $1 / 3 \mathrm{~h}_{\max }$ và phần trăm tương ứng được trình bày trên Hình 9 . Đối với kè ly tâm, sóng phía trước công trình có chiều cao từ $0,45 \mathrm{~m}$ đến $0,50 \mathrm{~m}$ chiếm tỷ lệ cao nhất và sóng phía sau công trình có chiều cao từ $0,085 \mathrm{~m}$ đến $0,090 \mathrm{~m}$ chiếm tỷ lệ cao nhất. Đối với kè Busadco, sóng phía trước công trình có chiều cao từ $0,65 \mathrm{~m}$ đến $0,70 \mathrm{~m}$ chiếm tỷ lệ cao nhất và sóng phía sau công trình có chiều cao từ $0,082 \mathrm{~m}$ đến $0,085 \mathrm{~m}$ chiếm tỷ lệ cao nhất. Đối với kè bán nguyệt, sóng phía trước công trình có chiều cao từ $0,55 \mathrm{~m}$ đến $0,60 \mathrm{~m}$ chiếm tỷ lệ cao nhất và sóng phía sau công trình có chiều cao từ $0,11 \mathrm{~m}$ đến trên 0,12 $\mathrm{m}$ chiếm tỷ lệ cao nhất. Có thể nhận thấy hiệu quả giảm sóng ứng với sóng có chiều cao $1 / 3$ $\mathrm{h}_{\max }$ của kè Busadco là hiệu quả nhất trong ba loại kè vì toàn bộ sóng sau khi truyền qua kè Busadco đều có chiều cao từ $0,082 \mathrm{~m}$ đến $0,085 \mathrm{~m}$.

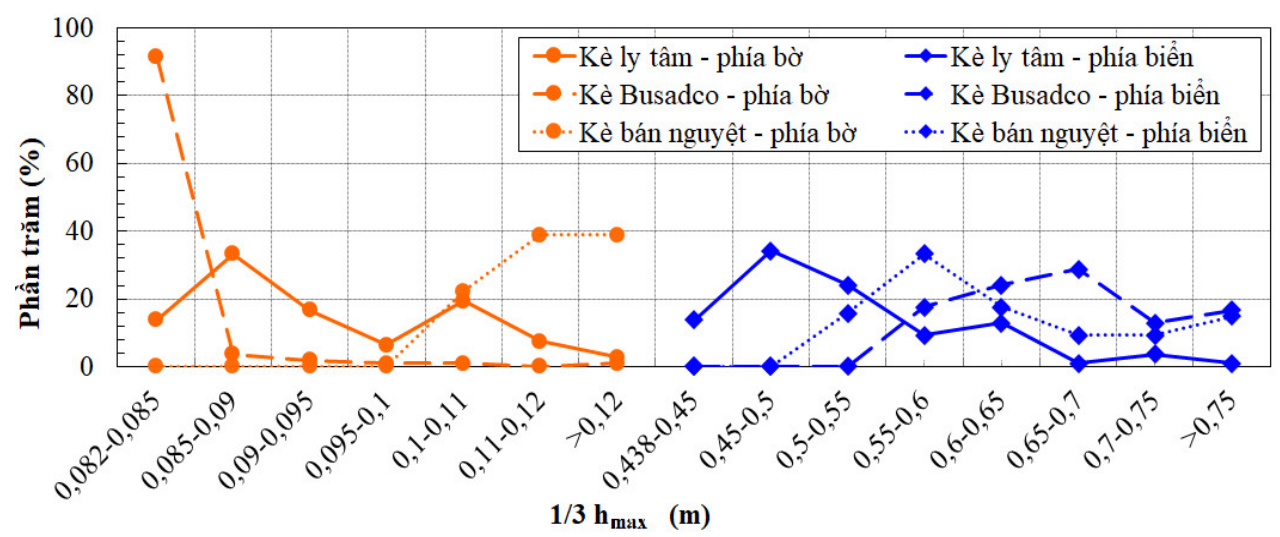

Hình 9. Biểu đồ quan hệ chiều cao và phần trăm sóng của $1 / 3 h_{\max }$ trước và sau kè ly tâm, kè Busadco và kè bán nguyệt.

Chiều cao sóng ứng với $1 / 10 \mathrm{~h}_{\max }$ và phần trăm tương ứng được trình bày trên Hình 10 . Đối với kè ly tâm, sóng phía trước công trình có chiều cao từ $0,6 \mathrm{~m}$ đến $0,65 \mathrm{~m}$ chiếm tỷ lệ cao nhất và sóng phía sau công trình có chiều cao từ $0,1 \mathrm{~m}$ đến $0,11 \mathrm{~m}$ chiếm tỷ lệ cao nhất. 
Đối với kè Busadco, sóng phía trước công trình có chiều cao trên $0,75 \mathrm{~m}$ chiếm tỷ lệ cao nhất và sóng phía sau công trình có chiều cao từ $0,098 \mathrm{~m}$ đến $0,1 \mathrm{~m}$ chiếm tỷ lệ cao nhất. Đối với kè bán nguyệt, sóng phía trước công trình có chiều cao trên $0,75 \mathrm{~m}$ chiếm tỷ lệ cao nhất và sóng phía sau công trình có chiều cao trên $0,12 \mathrm{~m}$ chiếm tỷ lệ cao nhất. Có thể nhận thấy hiệu quả giảm sóng ứng với sóng có chiều cao $1 / 10 \mathrm{~h}_{\max }$ của kè Busadco là hiệu quả nhất trong ba loại kè vì toàn bộ sóng sau khi truyền qua kè Busadco đều có chiều cao từ $0,098 \mathrm{~m}$ đến 0,1 $\mathrm{m}$.

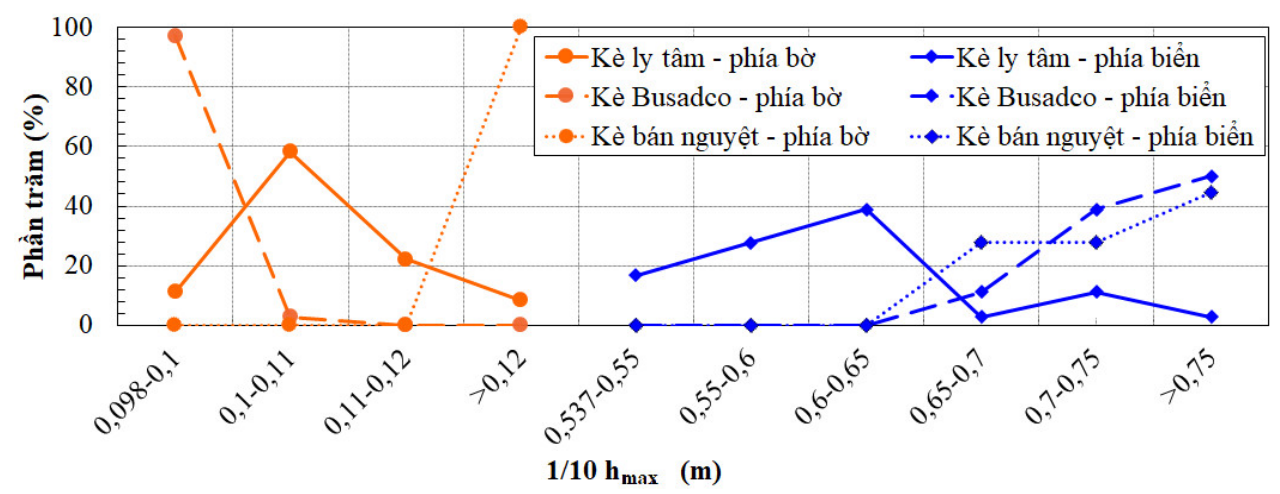

Hình 10. Biểu đồ quan hệ chiều cao và phần trăm sóng của $1 / 10 \mathrm{~h}_{\max }$ trước và sau kè ly tâm, kè Busadco và kè bán nguyệt.

Hiệu quả giảm chiều cao sóng của các loại kè được trình bày trên Hình 11 . Hiệu quả giảm chiều cao sóng được đánh giá với các chiều cao sóng trung bình $\left(\mathrm{h}_{\mathrm{tb}}\right), 1 / 3 \mathrm{~h}_{\max }, 1 / 10$ $\mathrm{h}_{\max }$ và $\mathrm{h}_{\max }$. Hiệu quả giảm sóng của kè ly tâm tương ứng với các chiều cao sóng $\left(\mathrm{h}_{\mathrm{tb}}, 1 / 3\right.$ $\mathrm{h}_{\max }, 1 / 10 \mathrm{~h}_{\max }$ và $\mathrm{h}_{\max }$ ) lần lượt là $86 \%, 83 \%, 82 \%$ và $81 \%$. Tương tự đối với kè Busadco lần lượt là $79 \%, 89 \%, 90 \%$ và $90 \%$; và kè bán nguyệt lần lượt là $83 \%, 82 \%, 81 \%$, và $80 \%$.

Có thể nhận thấy kè ly tâm có hiệu quả giảm sóng tốt nhất đối với chiều cao sóng cao nhất (đạt hiệu quả $86 \%$ ) và kè Busadco có hiệu quả giảm sóng tốt nhất đối với chiều cao sóng trung bình, $1 / 3 h_{\max }$ và $1 / 10 h_{\max }$ với hiệu quả giảm sóng tương ứng đều đạt gần $90 \%$. Nhìn chung, các loại kè đều đạt hiệu quả giảm sóng trên $80 \%$ đối với tất cả các chiều cao sóng ngoại trừ kè Busadco có hiệu quả giảm sóng đối với $\mathrm{h}_{\max }$ chỉ đạt $79 \%$.

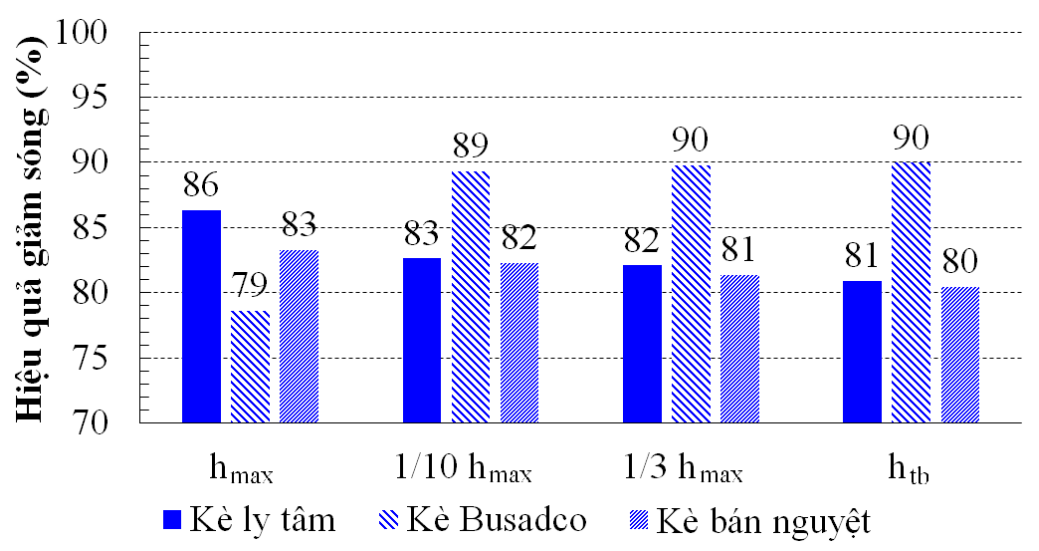

Hình 11. Biểu đồ thể hiện hiệu quả giảm chiều cao sóng kè ly tâm, kè Busadco và kè bán nguyệt.

Hiệu quả giảm năng lượng sóng của các loại kè được trình bày trên Hình 12. Có thể nhận thấy hiệu quả giảm năng lượng sóng của cả ba loại kè đều rất tốt khi đều đạt trên $95 \%$. Cụ thể, kè ly tâm và kè bán nguyệt có hiệu quả giảm năng lượng sóng đạt $97 \%$ trong khi kè Busadco có hiệu quả giảm năng lượng sóng tốt nhất khi đạt đến $99 \%$. Tuy nhiên, kết quả đánh giá này dựa trên dữ liệu đo đạc trong một khoảng thời gian ngắn nên cần quan trắc liên tục hoặc theo các mùa gió khác nhau để có đánh giá chính xác hơn về hiệu quả giảm sóng qua kè. 


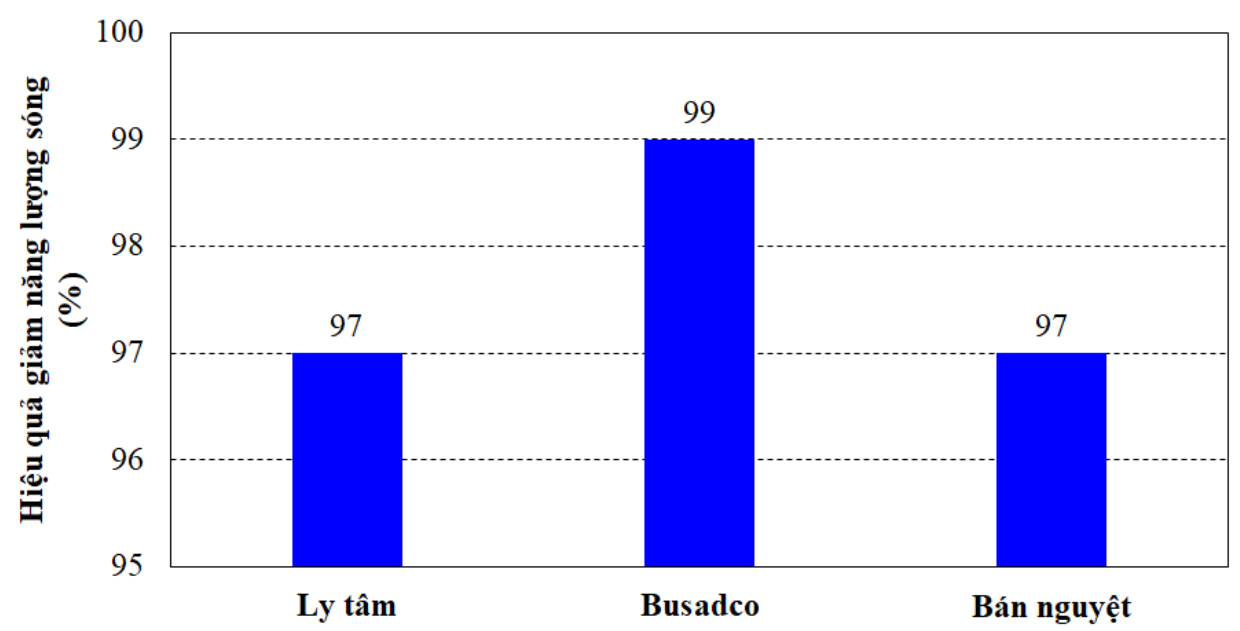

Hình 12. Biểu đồ thể hiện hiệu quả giảm năng lượng sóng kè ly tâm, kè Busadco và kè bán nguyệt.

\section{Kết luận}

Kết quả phân tích ảnh cho thấy bờ biển Tây tỉnh Cà Mau bị xói lở nghiêm trọng trong giai đoạn 2000-2020 với biến động rất lớn của đường bờ biển. Cụ thể, giai đoạn 2000-2013, đường bờ đã lấn sâu vào đất liền một đoạn gần $300 \mathrm{~m}$ và trong giai đoạn 2015-2018 đường bờ tiếp tục lấn vào đất liền một đoạn xấp xỉ $100 \mathrm{~m}$. Kết quả phân tích chuỗi ảnh vệ tinh Landsat và Google earth cho thấy rừng phòng hộ khu vực nghiên cứu đang suy giảm với tốc độ lần lượt là 7,76 và 8,18 ha/năm. Các ảnh vệ tinh chỉ được thu thập đến năm 2020 trong khi tuyến kè mới chỉ hoàn thành năm 2019 nên chưa thể có kết luận chính xác về khả năng chống xói lở và phục hồi rừng phòng hộ của các tuyến kè. Cần tiếp tục theo dõi diễn biến đường bờ bằng ảnh vệ tinh trong các năm tiếp theo.

Kết quả phân tích hiệu quả giảm chiều cao sóng ứng với các chiều cao $\mathrm{h}_{\max }, 1 / 3 \mathrm{~h}_{\max }$, $1 / 10 \mathrm{~h}_{\max }$ và $\mathrm{h}_{\mathrm{tb}}$ của kè ly tâm lần lượt là $86 \%, 83 \%, 82 \%$ và $81 \%$. Tương tự đối với kè Busadco lần lượt là $79 \%, 89 \%, 90 \%$ và $90 \%$; và kè bán nguyệt lần lượt là $83 \%, 82 \%, 81 \%$, và $80 \%$. Kết quả nghiên cứu dựa trên dữ liệu đo đạc trong một khoảng thời gian ngẳn nên chưa thể kết luận về hiệu quả cho toàn bộ các dạng kè này. Vì vậy, cần quan trắc liên tục hoặc theo các mùa gió khác nhau để có đánh giá chính xác hơn về hiệu quả giảm sóng qua kè.

Đóng góp của tác giả: Xây dựng ý tưởng nghiên cứu: N.N.T., T.V.T., T.V.H.; Lựa chọn phương pháp nghiên cứu: N.N.T., T.V.T., D.V.D.; Xử lý số liệu: N.N.T., T.V.T., D.V.D., H.N.N.; Lấy mẫu: N.N.T., T.H.L., T.K.H., T.V.Tuấn, T.M.Q.; Phân tích mẫu: N.N.T., T.H.L., T.V.T., T.V.H.; Viết bản thảo bài báo: T.V.T., D.V.D., H.T.C.H.; Chỉnh sửa bài báo: T.V.T., T.V.H., H.T.C.H.;

Lời cam đoan: Tập thể tác giả cam đoan bài báo này là công trình nghiên cứu của tập thể tác giả, chưa được công bố ở đâu, không được sao chép từ những nghiên cứu trước đây; không có sự tranh chấp lợi ích trong nhóm tác giả.

\section{Tài liệu tham khảo}

1. Karlsrud, K.; Vangelsten, B.V.; Frauenfelder, R. Subsidence and Shoreline Retreat in the Ca Mau Province - Vietnam Causes, Consequences and Mitigation Options. Geotech. Eng. J. SEAGS AGSSEA 2017, 48(1), 26-32.

2. GIZ. Integrated coastal protection and mangrove belt rehabilitation in the Mekong Delta. Integrated Coastal Management Programme (ICMP), 2016, pp. 236.

3. Vo, Q.T.; Kuenzer, C.; Oppelt, N. How remote sensing supports mangrove ecosystem service valuation: A case study in Ca Mau province, Vietnam. Ecosyst. Serv. 2015, 14, 67-75. 
4. Li, X.; Liu, J.P.; Saito, Y.; Nguyen, V.L. Recent evolution of the Mekong Delta and the impacts of dams. Earth Sci. Rev. 2017, 175, 1-17.

5. Thai, T.V.; Ha, N.H.; Hung, P.D.; Ngoc, N.D.; Tam, N.T. Hollow Cylinder Breakwater for Dissipation of Wave Energy to Protect the West Coast of Ca Mau Province in Vietnam. Proceedings of Vietnam Symposium on Advances in Offshore Engineering 2018, 599-605.

6. Thái, T.V.; Hà, N.H.; Hưng, P.Đ.; Ngọc, N.D. Đê trụ rỗng - Giải pháp mới ngăn sạt lở bờ biển. Khoa học \& Công nghẹ Việt Nam 2018, 9, 36-38.

7. Nghĩa, N.V.; Minh, H.V.T.; Luận, T.C.; Tỷ, T.V. Đánh giá hiệu quả giảm sóng của kè Busadco: trường hợp nghiên cứu tại Biển Đông và Biển Tây tỉnh Cà Mau. Tạp chí xây dụng 2020, 198-205.

8. Le Xuan, T.; Tran Ba, H.; Le Manh, H.; Do Van, D.; Minh Nguyen, N.; Wright, D. P.; Bui, V.H.; Mai, S.T.; Tran Anh, D. Hydraulic performance and wave transmission through pile-rock breakwaters. Ocean Eng. 2020, 218, 1-13.

9. Luom, T.T.; Phong, N.T.; Anh, N.T.; Tung, N.T.; Tu, L.X.; Duong, T.A. Using FineGrained Sediment and Wave Attenuation as a New Measure for Evaluating the Efficacy of Offshore Breakwaters in Stabilizing an Eroded Muddy Coast: Insights from Ca Mau, the Mekong Delta of Vietnam. Sustainability 2021, 13(9), 1-17.

10. Tình, T.V.; Phong, D.H. Sử dụng ảnh viễn thám và GIS nghiên cứu biến động đường bờ biển khu vực mũi Cà Mau. Tạp chí Khi tương Thủy văn 2017, 12, 35-40.

11. Tiến, N.N.; Cường, Đ.H.; Uu, Đ.V.; Sáo, N.T.; Tuấn, T.A.; Nam, L.Đ. Phân tích biến động đường bờ khu vực bờ biển cửa sông Hậu bằng tư liệu ảnh viễn thám. Tạp chí Khoa học và Công nghệ Biển 2017, 17(4), 386-392.

12. El Kafrawy, S.B.; Basiouny, M.E.; Ghanem, E.A.; Taha, A.S. Performance Evaluation of Shoreline Extraction Methods Based on Remote Sensing Data. $J$. Geogr. Environ. Earth Sci. Int. 2017, 11(4), 1-18.

13. Xu, H. Extraction of Urban Built-up Land Features from Landsat Imagery Using a Thematic Oriented Index Combination Technique. Photogramm. Eng. Remote Sens. 2007, 73(12), 1381-1391.

14. Ji, L.; Zhang, L.; Wylie, B.K. Analysis of dynamic thresholds for the normalized difference water index. Photogramm. Eng. Remote Sen. 2009, 75(11), 1307-1317.

15. Loveland, T.R.; Irons, J.R. Landsat 8: The plans, the reality, and the legacy. Remote Sens. Environ. 2016, 185, 1-6.

16. Malarvizhi, K.; Kumar, S.V.; Porchelvan, P. Use of High Resolution Google Earth Satellite Imagery in Land use Map Preparation for Urban Related Applications. Procedia Technololy. 2016, 24, 1835-1842.

17. MCBETH, F.H. A method of shoreline delineation. Photogramm. Eng. 1956, 22(2), 400-405.

18. Boak, E.H.; Turner, I.L. Shoreline Definition and Detection: A Review. J. Coastal Res. 2005, 21(4), 688-703.

19. Li, R.; Di, K.; Ma, R. 3-D Shoreline Extraction from Ikonos Satellite Imagery. Mar. Geod. 2003, 26, 107-115.

20. Tucker M.J.; Pitt E.G.E. Waves in ocean engineering. Amsterdam: Elsevier, 2001, pp. 521.

21. Lyman, T.P.; Elsmore, K.; Gaylord, B.; Byrnes, J.E.K.; Miller, L.P. Open Wave Height Logger: An open source pressure sensor data logger for wave measurement. Limnol. Oceanogr. Methods 2020, 18(7), 335-345.

22. Bộ Khoa học và Công nghệ. TCVN 12261:2018 Công trình thủy lợi - Kết cấu bảo vệ bờ biển - Yêu cầu thiết kế hệ thống công trình giữ cát giảm sóng. 2018, tr. 55 . 


\title{
Assessment of wave reduction effectiveness of detached breakwaters along the West coast of Ca Mau Province
}

\author{
Nguyen Ngoc Thuan ${ }^{1}$, Tran Van Ty ${ }^{2 *}$, Tran Van Hung ${ }^{2}$, Huynh Thi Cam Hong ${ }^{2}$, Ha \\ Ngoc Nhan ${ }^{2}$, Tran Hai Lam ${ }^{2}$, Dinh Van Duy ${ }^{2}$, Tran Khanh $\mathrm{Hai}^{3}$, Trinh Van Tuan ${ }^{3}$ và \\ Tran Minh Quang ${ }^{3}$
}

${ }^{1}$ IEE 24/7 Joint Stock Company; congtyiee24.7@gmail.com

${ }^{2}$ College of Engineering Technology, Can Tho University; tvty@ctu.edu.vn; tranvanhung@ctu.edu.vn; htchong@ctu.edu.vn; nhanb1705842@student.ctu.edu.vn; lamb1606132@student.ctu.edu.vn; dvduy@ctu.edu.vn

${ }^{3}$ Department of Agriculture and Rural Development of Ca Mau province; trankhanhhaisd@gmail.com; tuan0917177478@gmail.com; tranminhquangkbtb@gmail.com

\begin{abstract}
The objective of this study is to assess the shoreline changes and wave reduction effectiveness of the detached breakwaters constructed along the West coast of $\mathrm{Ca}$ Mau province. First, the satellite images including Landsat and images downloaded by Google earth tool (Google earth images) were processed to monitor the temporal changes of shoreline positions. Waves in front and behind detached breakwaters were measured and analyzed to assess the wave reduction effectiveness of different types of breakwaters. The image analysis results show that the area of protection forest has been reduced seriously (about $160 \mathrm{ha}$ ) in the last 20 years at the rate of 8.18 and $7.76 \mathrm{ha} /$ year for Landsat and Google earth images, respectively. The measured wave data shows that wave height reduction in terms of maximum wave height $\left(\mathrm{h}_{\max }\right), 1 / 10 \mathrm{~h}_{\max }, 1 / 3 \mathrm{~h}_{\max }$ and average wave height $\left(\mathrm{h}_{\mathrm{tb}}\right)$, respectively for the piles-breakwater type are $86 \%, 83 \%, 82 \%$ and $81 \%$; for the Busadco type are $79 \%, 89 \%, 90 \%$ and $90 \%$; and for the semi-circle type are $83 \%, 82 \%, 81 \%$, and $80 \%$. The effectiveness of wave energy reduction of all three types of detached breakwaters is found over $95 \%$. The analysis results are based on a short period of measured wave data, it is not possible to conclude on the effectiveness for all these breakwaters.
\end{abstract}

Keywords: West coast of $\mathrm{Ca}$ Mau province; Satellite images; Wave reduction effectiveness; Piles-breakwater; Semi-circle breakwater; Busadco breakwater. 